\title{
Vierastyövoiman työturvallisuuteen ja -terveyteen vaikuttavat tekijät
}

Kim O. Kaustell ${ }^{1)}$, Tiina E.A. Mattila ${ }^{2)}$, A-M Heiberg ${ }^{3)}$, R.H. Rautiainen ${ }^{4)}$

${ }^{1)}$ MTT Taloustutkimus, Latokartanonkaari 9,00790 Helsinki, kim.kaustell@mtt.fi

${ }^{2)}$ MTT Taloustutkimus, Latokartanonkaari 9,00790 Helsinki, tiina.mattila@mtt.fi

${ }^{3)}$ Landbrukets HMS-tjeneste, Storgata 4, N-3616 Kongsberg, Norja, anne.marie.heiberg@lhms.no

${ }^{4)}$ Risto Rautiainen, U of Nebraska, 984388 Nebraska Medical Center, Omaha, NE 68198-4388 USA, rrautiainen@unmc.edu

\section{Tiivistelmä}

Suomalaiset puutarha- ja maatilayrittäjät palkkaavat vuosittain noin 15000 ulkomaista työntekijää, pääasiassa kausityövoimaksi. Norjassa vastaava luku on 27000 (tiedot vuodelta 2007). Maatalous on yksi vaarallisimpia elinkeinoja, ja ulkomaalaistaustaisella työvoimalla on useiden tutkimusten mukaan kotimaista työvoimaa suurempi tapaturmariski. Ulkomaisen työntekijän tapaturmariskiä kasvattaa se, että hän on monessa riskiryhmässä samanaikaisesti.

Tässä Pohjoismaisen ministerineuvoston rahoittamassa tutkimushankkeessa olivat mukana Norja, Ruotsi ja Suomi. Hankkeen tavoitteena oli tunnistaa työturvallisuuteen ja -terveyteen vaikuttavia tekijöitä mm. haastattelujen ja työntekijöiden itsedokumentoinnin $(n=14)$ keinoin. Hankkeessa käytettiin hyväksi myös aiemmin vierastyövoimalle tehtyjä haastatteluja ( $\mathrm{n}=40)$.

Saadut tulokset vahvistavat aiemmissa tutkimuksissa saatuja tuloksia. Erityisiä kompastuskiviä työnteon turvallisuudelle ja terveellisyydelle olivat kielieroista johtuvat kommunikaatiovaikeudet, erot turvallisuusasenteissa, -tiedoissa ja -kulttuurissa, puutteellinen työkokemus sekä työntekijöiden pidättyvyys epäkohtien raportoinnissa työnantajalleen. Myös pitkät työpäivät sesongin aikana sekä urakkapalkkaus saattavat suoraan tai välillisesti nostaa tapaturmariskiä. Vakituisesti ulkomailla asuvien työntekijöiden koti-ikävä näyttää heikentävän työhyvinvointia.

Jatkohankkeessa v. 2012..2013 tuloksista jalostetaan työkaluja, joita voidaan käyttää vierastyövoimaa palkkaavilla tiloilla mm. monipuolistamaan turvallisuuteen liittyvää kommunikaatiota ja koulutusta. Tutkimuskokonaisuutta rahoittavat Pohjoismainen ministerineuvosto, Työsuojelurahasto sekä Stiftelsen KSL Matmerk (Norja).

\section{Asiasanat}

Vierastyövoima, työturvallisuus, työterveys, työhyvinvointi, maatalous, puutarhatalous 


\section{Johdanto}

Puutarha/maatila on maailmanlaajuisesti yksi vaarallisimmista työpaikoista. Euroopassa maatalous sijoittuu yhdessä rakentamisen ja teollisuuden kanssa kärkipäähän tapaturmaluvuissa. USA:ssa maataloudessa sattui 26 kuolemaan johtanutta tapaturmaa sataatuhatta työntekijää kohden vuonna 2009, kun kaikilla aloilla keskimäärin tapaturmia sattui 3.3 per satatuhatta työntekijää (CFOI 2010). Euroopassa maataloustöissä vastaava luku oli 8.8 ja kaikilla aloilla 2.8 vuonna 2007 (Eurostat 2011). Suomessa maatalousyrittäjille sattui 5 kuolemaan johtanutta tapaturmaa vuonna 2009. Tässä luvussa eivät ole mukana työsuhteessa olleiden tapaturmat. Suomalaiset puutarha- ja maatilayrittäjät palkkaavat vuosittain noin 15000 ulkomaista työntekijää, pääasiassa kausityövoimaksi. Ala on tunnetusti vaarallinen ja ulkomaisella työntekijällä on useiden tutkimusten mukaan suurempi alttius joutua tapaturmaan.

Turvallisen työympäristön aikaansaaminen edellyttää yhteistyötä ja avointa keskustelua. Myös laki velvoittaa työntekijää ja työnantajaa yhteistoiminnassa ylläpitämään ja parantamaan työpaikan turvallisuutta. Käytännössä kuitenkin muun muassa lyhyet työsuhteet, puutteellinen kielitaito, sosiaalinen stressi, erilaiset asenteet turvallisuuteen tai tottumus erilaiseen johtamiskulttuuriin voivat asettaa rakentavalle yhteistyölle haasteita.

Hankkeen tavoitteena oli tunnistaa ulkomaisen työvoiman työturvallisuuteen ja -terveyteen vaikuttavia tekijöitä Pohjoismaissa. Tietoa tarvitaan, jotta voitaisiin kehittää kohderyhmän työturvallisuutta, työterveyttä ja työviihtyvyyttä ja siten myös parantaa ulkomaisen työvoiman saatavuutta jatkossa alalla, jossa kotimaisesta työvoimasta on pulaa.

\section{Aineisto ja menetelmät}

Hankkeessa tehtiin kirjallisuustutkimuksen lisäksi työntekijöiden haastatteluja ja sovellettiin kohdehenkilön itsedokumentointiin perustuvaa, ns. Luotain-menetelmää (Mattelmäki 2006, Gaver ym. 1999). Menetelmän keskeinen tavoite on tuottaa koehenkilön itsedokumentoinnin keinoin mahdollisimman lähellä todellista tarkasteltavaa tapahtumaa olevaa sisältöä, jonka avulla pyritään vastaamaan tutkimuskysymyksiin. Tässä tutkimuksessa itsedokumentoinnin keskeinen osa oli päiväkirja, joka sisälsi mm.

- Päivittäin kirjattavia tietoja (työpäivän alku ja loppuajat, työtehtävät, vireystila päivän alussa ja lopussa)

- $\quad$ Päivittäisen teemakysymyksen esim. työpaikan sosiaalisesta ilmapiiristä

- Työhön, työpaikkaan ja työtovereihin liittyviä väittämiä, jotka koehenkilöt arvioivat viisiportaisella asteikolla "täysin samaa mieltä” - ”täysin eri mieltä”. Väittämät perustuivat Ostrom ym. (1993) tekemään, työturvallisuuskulttuuria luotaavaan menetelmään.

- Työmotivaatiotekijöiden arvottamistehtävän

- Tilaa vapaille kommenteille ja muistiinpanoille

Päiväkirjat sekä niihin liittyvä ohjeistus käytiin kahdella eri tilalla olleen neljäntoista koehenkilön kanssa läpi ennen dokumentoitavaa työviikkoa. Työviikon jälkeen päiväkirjat koottiin ja niissä ollut aineisto käsiteltiin tutkimusryhmässä soveltaen ns. affiniteettianalyysiä (Beyer and Holzblatt 1998). Analyysissä tulkittiin ja ryhmiteltiin aineistosta löytyvä dokumentaatiomateriaali teemoittain. Tulkintojen oikeellisuus varmistettiin palaamalla tiloille ja keskustelemalla niistä koehenkilöiden kanssa.

Hankkeen tulosten johtamisessa käytettiin hyväksi myös aiemmin vierastyövoimalle tehtyjä haastatteluja $(n=40)$.

\section{Tulokset ja tulosten tarkastelu}

\section{Kirjallisuustutkimuksen tuloksia}

Euroopassa on tutkittu ulkomaisen työvoiman työterveyttä ja hyvinvointia melko vähän verrattuna esim. USA:ssa tehtyjen tutkimusten määrään. Tässä hankkeessa tunnistettiin yksitoista uudehkoa eurooppalaista, maatiloilla työskentelevää vierastyövoimaa koskevaa tutkimusjulkaisua. Suomessa maatalouden kausityövoiman terveydentilasta ei löytynyt haussamme julkaistuja tutkimuksia, mutta maahanmuuttajia, joista osa tulee samoilta alueilta kuin lyhytaikainenkin työvoima, on tutkittu jonkin verran. Pohjanpää ym. (2003) tutkimuksen mukaan maahanmuuttajilla (Suomessa asuvia venäläisiä, virolaisia, somaleja ja vietnamilai- 
sia) oli erilaisia oireita kuten päänsärkyä, selkäkipuja ja unettomuutta hieman enemmän ja hampaat selvästi huonommassa kunnossa kuin suomalaisilla keskimäärin. Pääosa (90-70 \%) maahanmuuttajista piti terveydentilaansa hyvänä, poikkeuksena venäläiset joista vain 55 \% piti terveydentilaansa hyvänä. Samansuuntaisia tuloksia saivat Vartia \& Giorgiani (2007), joiden tutkimuksen mukaan suurin osa maahanmuuttajista piti terveydentilaansa ikäisiinsä verrattuna hyvänä, venäläisistä hieman muita suurempi osuus keskinkertaisena. Vartian \& Giorgianin (2007) tutkimukseen osallistuneet olivat Suomessa töissä olevia maahanmuuttajia useista eri kansalaisuuksista (joukossa ei ollut maatalousalalla työskenteleviä).

Sekä lähtömaan että tulomaan olosuhteet vaikuttavat henkilöiden terveyteen ja hyvinvointiin. Usein vapaaehtoisesti muualle töihin lähtevien henkilöiden terveys on suhteellisen hyvä johtuen siitä, että lähtijöiksi valikoituu pääasiassa nuoria ja työkykyisimpiä. (Smith ym. 2000; Malin \& Gissler 2006). Maahantulosyyt vaihtelivat, Venäjältä tulleet olivat pääasiassa inkeriläisiä paluumuuttajia, somalit pakolaisia tai turvapaikanhakijoita, ja Virosta tulleista isoin osa oli tullut Suomeen töihin/työn hakuun tai oli inkeriläinen paluumuuttaja. Maahanmuuttajien tausta ja ikärakenne saattaa olla hyvin erilainen kuin Suomeen töihin tulevilla kausityöntekijöillä, eivätkä tulokset sen vuoksi kerro kausityöntekijöiden terveydentilasta. Lisäksi kausityöntekijät tulevat hyvin laajalta alueelta. Monissa lähtömaissa, esimerkiksi Venäjällä tai Puolassa, taudit kuten tuberkuloosi ja salmonella ovat yleisempiä kuin Suomessa. Toiminnasta tartuntatautitapauksissa ja niiden ehkäisyssä tulisikin olla selvät ohjeet. Norjassa on raportoitu salmonellan (Salmonella Enteritidis) löytymisestä mansikanpoimijoilta (Guerin ym. 2005).

Käytännössä vierastyövoima kuuluu useampaan riskiryhmään samanaikaisesti, minkä vuoksi työtapaturman ja ammattiataudin riski on kohonnut. Riskitekijöitä on monia, mutta keskeisintä on niiden kertyminen, ei niinkään työntekijän kansalaisuus. Puutteellinen koulutus tehtäviin töihin, yhdistettynä keskimääräistä vaarallisempiin ja/tai toistuviin työtehtäviin sekä ansaitsemismielessä tehtyihin ylipitkiin työpäiviin lisää tapaturman ja ammattitautien vaaraa (Ahonen ym. 2009; Garcia ym. 2009, McKay ym. 2006). Samansuuntainen vaikutus on heikosta kielitaidosta ja turvallisuusosaamisesta johtuva puuttellinen kyky kommunikoida turvallisuus- ja terveysasioita (McKay ym. 2006, Corvalan ym. 1994). Myös lyhyet työsuhteet ja maassaolo heikentävät työturvallisuutta (Corvalan ym. 1994; Salminen ym. 2009). Salmisen ym. (2009) mukaan yli viisi vuotta työskennelleillä vierasmaalaisilla työntekijöillä oli vähemmän tapaturmia kuin lyhyemmän aikaa työskennelleillä. Corvalan ym. (1994) esittää, että erilaiset työtavat ja mm. eristyneisyyden ja epätietoisuuden/turvattomuuden kokemukset voivat olla tapaturmien riskitekijöitä. Tilapäistyö on kansallisuudesta riippumatta merkittävä työturvallisuu- ja terveysriski (Patussi ym. 2008), ja sitä kohottaa edelleen urakka- tai suoriteperusteinen palkkaus (Johansson ym. 2010).

\section{Kuormitustekijät ja palautuminen}

Luotain-tutkimuksessa olleiden työntekijöiden ( $N=14)$ työpäivien keskipituus vaihteli 6 ja 14 tunnin välillä, pisimmän työpäivän ollessa 15 tuntia. Työ oli ollut usein monotonista, nopeatempoista (esim. tuotteiden pakkaaminen urakkapalkalla); käsin tehtävät nostot raskaita ja työ siten uuvuttavaa. Henkistä kuormitusta lisäsivät kiireen ja pakkotahtisuuden ohelle työpaikan sosiaaliset suhteet - erityisesti jos sama ryhmä myös asui tiiviisti yhdessä. Toisaalta hyvin toimivia työpaikan ihmissuhteita pidettiin tärkeänä palautumisen ja virkistyksen lähteinä. Muita viihtyvyyteen ja palautumiseen liittyviä tekijöitä olivat levon ohella hyvä ruoka, yhteydenpito perheeseen ja ystäviin kotimaassa sekä liikunta. Työpäivän pituudella ja vireystilan muutoksella työpäivän aikana ei havaittu tilastollisesti merkitsevää yhteyttä. Koti-ikävä nousi useassa haastattelussa esiin työntekijän hyvinvointia haittavana tekijänä.

\section{Turvallisuustietoisuus}

Haastatellut työntekijät kokivat työpaikkansa turvallisiksi ja sanoivat tunnistavansa siellä olevat vaaarat hyvin. Kysyttäessä esimerkkejä useimmat eivät kuitenkaan osanneet nimetä vaarallisia kohteita tai tehtäviä. Useimmin tulivat mainituiksi kemialliset vaarat (kasvinsuojeluaineet), liukastumis-, kompastumis- ja putoamisvaarat, putoavat esineet, liikkuvat työkoneet ja terävät työvälineet. Koehenkilöt kokivat, että he voivat vapaasti raportoida työnjohdolle havaitsemistaan työturvallisuusepäkohdista ja myös kieltäytyä vaarallisiksi katsomistaan työtehtävistä. Jälkimmäistä tilannetta ei kuitenkaan ollut esiintynyt. Toisaalta jotkut koehenkilöt katsoivat parhaaksi korjata vaaralliseksi koettu kohde häiritsemättä työnjohtoa asialla. Kielierojen lisäksi esimerkiksi kulttuurierot tai ujous vaikeuttavat keskusteluja. Hyvänä käytäntönä työntekijät mainitsivat henkilöstöpalaverit, joissa yhdessä keskusteltiin muun muassa töistä, turvallisuudesta ja vaaratilanteista. Tällöin hiljaisemmatkin voivat oppia toisten kokemuksista.

Työntekijät kokivat myös kollektiivista vastuuta yksittäisten työntekijöiden turvallisuudesta. Kyky 
tunnistaa ja hallita työn vaaroja kasvaa ammattitaidon kehittymisen myötä, mutta usein maatilalle töihin pyrkivällä ei ole alan koulutusta tai työkokemusta. Kokeneita työntekijöitä saatetaan käyttää uusien työntekijöiden perehdyttämiseen turvallisiksi havaittuihin työmenetelmiin ja ”talon tapoihin”.

\section{Työmotivaatio}

Koehenkilöitä pyydettiin arvioimaan 15 motivaatiotekijän merkitystä omassa päätöksessään hakeutua ulkomaille töihin. Rahan ansaitseminen on taustatekijöistä riippumatta pääasiallisin syy ulkomailla työskentelyyn (Kuvio 1). Työntekijän ikä, sukupuoli tai työjaksojen lukumäärä kyseisellä tilalla eivät vaikuttaneet tähän. Yli kolme kertaa samalle tilalle palaavien joukossa matkailun, virkistyksen, uusien kokemusten ja lähtömaan olosuhteiden merkitys oli pienentynyt. Näiden tilalle nousivat työpaikan hyvät työolosuhteet, viljelijän antama tunnustus hyvästä työstä sekä työn miellyttävyys.

\section{Motivaatiotekijät $(\mathrm{N}=14)$}

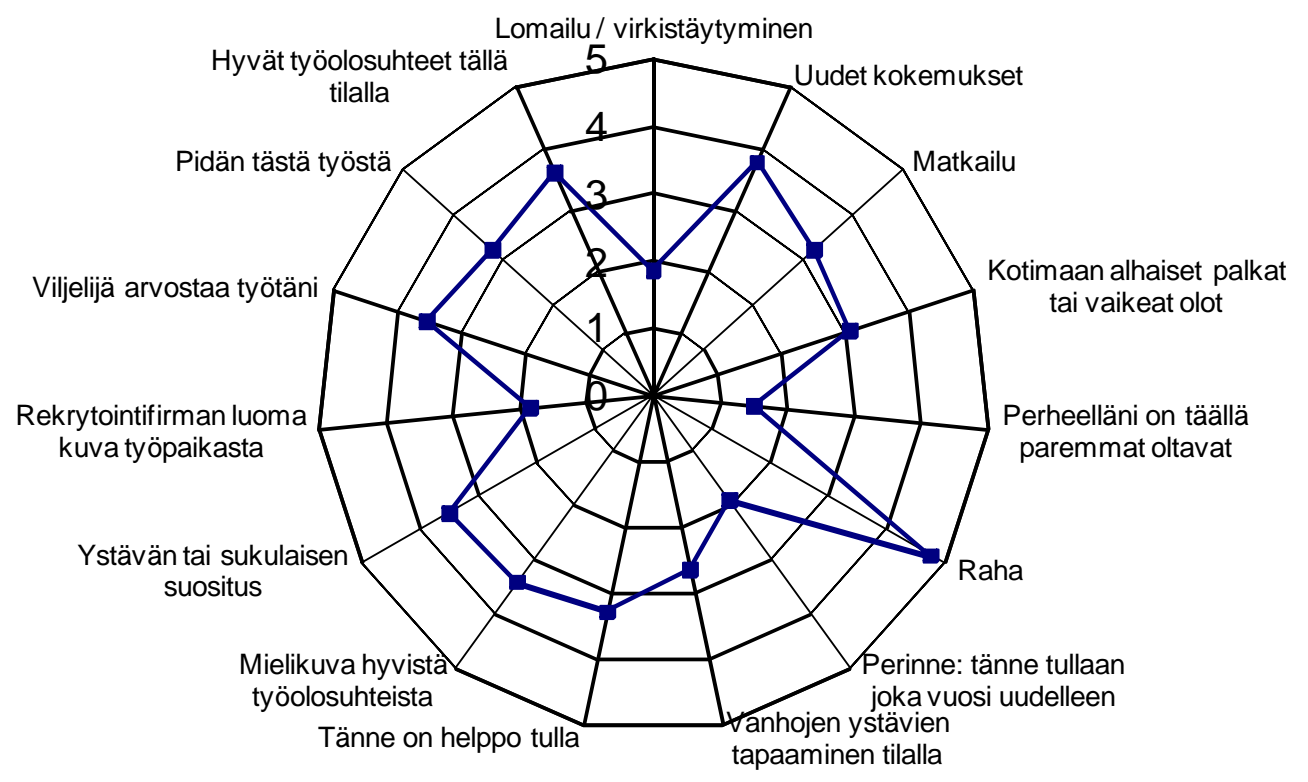

Kuva 1. Motivaatiotekijöiden painoarvot.

\section{Johtopäätökset}

Useimpien päällimmäinen motivaatio ulkomailla työskentelyyn on rahan ansaitseminen. Monet työntekijät haluavat keskittyä työntekoon, tehdä pitkiä työpäiviä ja säästää rahaa. Työpäivien toistuva venyminen on sinänsä jo työturvallisuusriski. Lisäksi keskittyminen pelkästään työhön, tinkiminen palautumisajasta ja esimerkiksi terveellisestä ruokavaliosta voivat pidemmän päälle johtaa työ- ja keskittymiskyvyn heikentymiseen.

Työntekijät arvostavat hyviä työolosuhteita. Ulkomaiset työntekijät mainitsivat hyvät työolot, rahan ansaitsemisen jälkeen, yhtenä voimakkaimmista motivaatiotekijöistä, miksi tänne tullaan töihin. Työnantaja voisi palkita myös työturvallisuuden kehittämisestä, esimerkiksi järjestämällä ideakilpailun työturvallisuusaloitteista. Pienikin bonus voittajan tilissä voi olla hyvä kannustin ja tuottaa käyttökelpoisia ideoita työturvallisuuden kehittämiseen.

Hyvä kokemus kannustaa tulemaan töihin uudelleen ja toisaalta työntekijät suosittelevat helposti lähipiirilleen hyväksi kokemaansa tilaa tai tuovat tuttavan mukanaan seuraavana vuonna. Hyvät työolot toimivat näin apuna myös työvoiman rekrytoinnissa. 


\section{Kirjallisuus}

Ahonen, E.Q., Porthé, V., Vázquez, M.L., Garcia, A.M., López-Jacob, M.J., Ruiz-Frutos, C., Ronda-Pérez, E., Benach, J. \& Benavides F.G. 2009. A quality study about immigrant workers’ perceptions of their working conditions in Spain. J Epidemiol Community Health vol 63: 936 - 942.

Beyer, H. \& Holtzblatt, K. 1998. Contextual Design. San Francisco, USA: Morgan Kaufmann.

CFOI 2010. Number and rate of fatal occupational injuries, by industry sector 2009. United States Department of Labor: Bureau of Labor Statistics. Saatavissa: http://www.bls.gov/iif/oshwc/cfoi/cfch0008.pdf (Tark. 30.6.2011)

Corvalan, C.F., Driscoll, T.R. \& Harrison J.E. 1994. Role of migrant factors in work-related fatalities in Australia. Scandinavian Journal of Work, Environment and Health vol 20 (5): 364-370.

Eurostat 2011. Standardised incidence rate of accidents at work by economic activity, severity and age (rate per 100000 workers). Saatavissa:

http://nui.epp.eurostat.ec.europa.eu/nui/show.do?dataset=hsw_aw_inaag\&lang=en (Tark. 27.6.2011)

Garcia, A.M., Lopez-Jacob, J.M., Agudelo-Suarez, A.A., Ruis-Frutos, C., Ahonen, E.Q. \& Porthe V. 2009. Occupational health of immigrant workers in Spain (MAL project): key informants survey. Gaceta Sanitaria vol 23 (2): $91-97$.

Gaver, W., Dunne, T. \& Pacenti, E. 1999. Design: cultural probes. Interaction vol 6 (1): 21-29.

Guerin, P.J., Vold, L. \& Aavitsland P. 2005. Communicable disease control in a migrant seasonal workers population: a case study in Norway. Eurosurveillance vol 10 (1-3): 48 - 50.

Johansson, B., Rask, K. \& Stenberg, M. 2010. Piece rates and their effects on health and safety - A literature review. Applied Ergonomics vol 41: 607 - 614.

Malin, M. \& Gissler M. 2006. Maahanmuuttajien terveys- ja sosiaalipalveluiden saatavuus, laatu ja käyttö oikeudenmukaisuuden näkökulmasta. In: Hyvinvointivaltion rajat, Riittävät palvelut jokaiselle, Näkökulmia yhdenvertaisuuteen sosiaali- ja terveydenhuollossa. Helsinki, Stakes. 188 s.

McKay, S., Craw, M. \& Chopra, D. 2006. Migrant workers in England and Wales. An assessment of migrant worker health and safety risks. Working Lives Research Institute, London Metropolitan University. London. 273 s.

Mattelmäki, T. 2006. Design probes. Academic dissertation. Publication Series of the University of Art and Design. Helsinki A 69.

Ostrom, L., Wilhelmsen, C. \& Kaplan, B. 1993. Assessing safety culture. Nuclear safety vol 34 (2): 163-172.

Patussi, V., Barbina, P., Barbone, F., Valent, F., Bubbi, R., Caffau, C., Driussi, C., Munafó, G., Rosolen, V., Venturini, C., Zanin, T. \& Zuliani, C. 2008. Comparison of the incidence rate of occupational injuries among permanent, temporary and immigrant workers in Friuli-Venezia Giulia. Epidemiol Prev vol 32 (1): 35 - 38.

Pohjanpää, K., Paananen, S. \& Nieminen, M. 2003. Maahanmuuttajien elinolot. Venäläisten, virolaisten, somalialaisten ja vietnamilaisten elämää Suomessa 2002. Elinolot 2003: 1. Tilastokeskus. 241 s. 
Salminen, S., Vartia, M. \& Giorgiani, T. 2009. Occupational injuries of immigrant and Finnish bus drivers. Journal of Safety Research 40: 203 - 205.

Smith, G.D., Chaturvedi, N., Harding, S., Nazroo, J. \& Williams, R. 2000. Ethnic inequalities in health: a review of UK epidemiological evidence. Critical Public Health vol 10: 375 - 408.

Vartia, M. \& Giorgiani, T. 2007. Työstressi ja tyytyväisyys työhön ja elämään. In: Vartia, M., B. Bergbom, T. Giorgiani, A. Rintala-Rasmus, R. Riala, R. \& S. Salminen (2007), Monikulttuurisuus työn arjessa. Työterveyslaitos, Helsinki. ss. $143-154$. 